\title{
Political instability And discontinuity in Nigeria: The PRE-COLONiAL PAST AND PUBLIC GOODS PROVISION UNDER COLONIAL AND POST-COLONIAL POLITICAL ORDERS
}

\section{Kostadis J. PAPAioAnNou and Angus DALRYMPle-Smith}

Kostadis J. Papaioannou is a Ph.D. candidate at the rural and environmental history group at Wageningen University and affiliated with Utrecht University, the Netherlands. The corresponding author, he may be reached at kostadis.papaioannou@wur.nl. Angus Dalrymple-Smith is a Ph.D. candidate at the rural and environmental history group at Wageningen University, the Netherlands. He may be reached at angus.dalrymple-smith@wur.nl.

\section{Abstract}

This article explores the relative importance of pre-colonial institutional capacity and the effects of periods of peace and stability on long-term development outcomes in Nigeria. We use data on education, health, and public works at a provincial level from a variety of colonial and Nigerian state sources to apply a decade-by-decade analysis of public goods provision in Nigeria from 1900 to 2010. Using a newly constructed measure of pre-colonial institutional capacity our results suggest that colonial-era investments were influenced by pre-colonial conditions and that the pax colonia allowed for a strong path dependency until the second world war. Contrary to other studies, which find evidence of pre-colonial centralization affecting current outcomes. In particular, we find that the post-1945 era saw a break in the pattern developed earlier in the century. Rising regionalism from the 1950s led to violent conflict and military dictatorship and caused decades of unstable and unpredictable patterns of investment which ended only with the reestablishment of democracy in the 1990s. Therefore, a key explanatory variable to understanding patterns of public goods provision seems to be the level of political stability which the Nigerian state experienced at different points during the 20th century.

$\mathrm{T}$ he news that the leader of South Sudan's opposition and rebel movement was seen reading a copy of Why Nations Fail in order to "to reflect on whether he is making the right decisions" is evidence of the wide-ranging influence of New Institutional Economics (NIE). This strand of academic thought sees weak institutional arrangements as the ultimate, most significant barrier to economic growth. Proponents have argued that weak states which cannot or will not protect property rights and functioning markets will be unable to provide their citizens with the public goods necessary for long term development. In the case of Africa, one important strand of this literature has suggested that regions which experienced greater levels of precolonial centralization have, since their independence, also seen higher levels of public goods provision through a greater level of state capacity. However, to define state centralization, in the pre- as well as in the post-colonial eras, in the context of Africa is problematic as measures such as population density, which have served as a suitable proxy in Europe and Asia, have been found to be unsatisfactory. To address this problem, economic historians have used a centralization variable taken from either the Murdock Standard Cross Cultural data set or from an updated version maintained by Douglas White at the University of California, Irvine. This article extends this research in two ways: First, it analyzes the decades between the pre-colonial past and the present to learn about the extent to which the present may have been determined by the pre-colonial past. Second, it suggests a new way to measure the degree of state centralization in the era before the arrival of Europeans. ${ }^{1}$

Beginning in the 1990s, a series of articles began to use econometric cross-country regressions in an effort to pinpoint the underlying cause of world economic inequality. A seminal study within the African context is the work of Michalopoulos and Papaioannou who document a strong association between pre-colonial political centralization and contemporary development. Another well cited article is that of Gennaioli and Rainer who argue that pre-colonial centralization predicts better modern-day outcomes, but in this instance focusing on education, health, and infrastructure rather than inequality. These studies have provided important insights into the role of deeply rooted pre-colonial institutions in shaping comparative regional development within African countries. However, other scholars suggest that such an approach is perhaps too deterministic and that an understanding of exactly how the past has influenced present-day outcomes requires investigating the long-term patterns of historical change. In this regard, it is important to appreciate that Murdock's cross-cultural samples and his ethnographic Atlas do not properly capture data on 
pre-colonial centralization to begin with, as we will argue in the next section. ${ }^{2}$

We test the broad claim that the pre-colonial past still influences the present through a case study of public goods provision in Nigeria from 1900 until the 2000s. As Nigeria emerges as Africa's largest economy, and is predicted to soon become the world's third most populous nation, it is crucial to understand how the nation's history has influenced its development. Nigeria is very well suited to a study of historical complexity. The modern country of Nigeria contained within its pre-colonial borders the Sokoto caliphate, one of the most powerful and centralized indigenous African states of the 19th century, as well as smaller political entities such as the Yoruba successor states and the so-called "acephalous" regions of the Southeast. Different regions were integrated into both the Atlantic and Saharan economies, and inter-regional trade was long established. In addition, the country has had a range of religious traditions, from the relatively long-established tradition of Islam in the north to the missionary-led adoption of Christianity in the south, and to many regions where local religions have survived or been integrated into the imported Abrahamic traditions. During the course of the 20th century, today's Nigeria saw a succession of economic, political, and military shocks which followed the imposition, establishment, and end of colonialism. We use a newly developed measure of pre-colonial centralization to capture the degree of state capacity within each of Nigeria's present-day provincial borders before the arrival of the British. This is then correlated with a decade-by-decade, state-level analysis of government and nongovernment investments in human and physical capital. ${ }^{3}$

We argue that the relative peace imposed by the early colonial state allowed pre-colonial institutions to determine the nature of public goods provision. However, in the post-colonial period the country experienced nearly four decades of political and military instability. The rise and fall of successive military regimes and unstable civilian governments effectively broke the patterns of investment established in the first half of the century. Our data suggests that it was not until the establishment of (relatively) stable democratic governments in the 1990s that correspondingly stable patterns of development re-emerged, ending decades of uneven region-driven policies.
We interpret our findings as evidence to support the view that history does not necessarily constrain outcomes in the present and that policymakers need to be wary of viewing the past as deterministic. Our work adds support to literature that finds a strong negative connection between unaccountable dictatorial regimes and long-term development. ${ }^{4}$

\section{Methods and data \\ Pre-colonial centralization}

To measure the impact of pre-colonial centralization many scholars, especially in the field of economic history, have relied on the aforementioned cross-cultural sample compiled by Murdock. This vast work, based on anthropological observations, attempted to classify and code various aspects of different cultures around the world. One of these codes - 32r/32t — assigned ethnic groups to one of four levels of "Jurisdictional Hierarchy" and has been used as a means of quantifying the extent to which "cultures," based on ethno-linguistic criteria, possessed complex institutional arrangements in the era before the arrival of European rule. But Murdock's Atlas does not in fact present a measure of institutional differences in the pre-colonial period and instead uses observations from around 1870 till 1960, ca. 90 years. In the case of Nigeria, the differences in this regard are striking: 71 percent of the observations included by Murdock occurred 
after 1920 and 22 percent after 1940. Furthermore, by focusing on individual ethno-linguistic groups, the observations ignore the development of complex, multi-ethnic political entities and empires in 19th-century Africa. Thus it is necessary to find a new method with which to better capture the realities of the continent in the 1870s and 1880 s, and specifically the concept of pre-colonial centralization. ${ }^{5}$

Although many of their conclusions are notably different, both Herbst, on one side, and Oasafo-Kwaako and Robinson, on the other, argue that definitions of political centralization developed for Europe are largely unsuitable in the sub-Saharan context. For example, in Europe, high-density populations and relatively limited, valuable land made conquest both possible and profitable. It also meant that states needed to be internally cohesive, with well-defended borders and the resources of the entire nation well-harnessed, in order to develop relations with, and control over, a country's hinterlands. Cities became important centers where capital could be raised for purposes of trade, defense, and aggression. Therefore, a successful European state, as defined by Max Weber and amplified by scholars such as Charles Tilly, was one where a human community was capable of claiming monopoly over the legitimate use of force within a given territory. The instrument of the state relies on its legitimacy, but also on constitutive elements such as a government, a military force, a territory, and the power of an administration to raise taxes from its constituents. Any administration should be able to maintain a satisfactory degree of civil order, be able to secure state's boundaries, issue and control a currency, provide public services, and raise public revenues to sustain the administration. ${ }^{6}$

Jeffrey Herbst, for example, argues that such a definition cannot hold true for pre-colonial, nor even for colonial or post-colonial Africa. A number of decisive factors prevented the establishment of the kind of centralized states characteristic of Europe. The terrain itself prevented the development of efficient infrastructure. Water-based travel was limited, the wheel often impractical, and beasts of burden excluded from much of the continent due to the disease-bearing tsetse fly. Even more crucial was the combination of very low population densities and the availability of huge swaths of unoccupied territory, which together always allowed the possibility of simply moving to escape the control of any predatory state or states. Furthermore, much of African agriculture was rain-fed and required little of the investment that might convince people to turn to a state for capital or protection. This meant, first, that wealth came to be defined by control over people, not land, and, second, that states were always fluid and dynamic entities, based on temporary loyalties, coercion, and the power of a
A famous book, Why Nations Fail, argues that pre-colonial institutions are partly responsible for post-colonial economic outcomes in developing nation states. But the institutional literature takes an approach that is perhaps too deterministic. This article re-examines the Nigerian case with alternative historical data and comes to a different conclusion: Inertial forces of the pre-colonial past may not determine the postcolonial present. The present has failings, and successes, all of its own.

military elite. Tribute, rather than tax would be paid as long as the center was powerful enough to project itself to hinterlands that otherwise could break away with ease. Therefore, successful African "states"-or, more particularly, coalitions of elites within a particular territory - were those that were able to successfully broadcast power from tightly controlled, but territorially limited, power centers. An example is the Asante "state," which was based around matrilineal kinship ties centered on the king, or Asantehene, in its central territories around Kumasi. This state then exercised power in ever decreasing circles of influence away from the capital. Another illustration from pre-colonial Nigeria might be the ribats, or new towns, established by the Sokoto caliphate in the 19th century, which allowed the broadcasting of power to newly conquered territories without ever seeking to directly control the surrounding territories. ${ }^{7}$

What is needed therefore is a way of defining the extent to which elites in various African territories could effectively broadcast power and maintain their influence. One approach, which also carries considerable influence within the field of New Institutional Economics (NIE), is that of Douglass North and his co-authors. Their hypothesis is that the majority of states, or political orders, around the world today and throughout history work by aligning "the interests of powerful individuals to forge a dominant coalition in such a way that limits violence and makes sustained social interaction possible on a larger scale." Classified and labeled as "limited access order (LAO) or natural states," they posses two fundamental characteristics: (1) they limit access to organizational form and (2) they control trade. Recognizing that elites in certain states are more effective at exercising authority and promoting order, North, et al. divide LAO states into three groups, fragile, basic, and mature. For each, they then describe the extent to which governing coalitions are stable against external and internal shocks, are able to facilitate more complex economic and political activities, and can constrain and manage violence among themselves. Thus, a fragile natural state for instance is characterized by "commitments within the dominant coalition (which) are fluid and unstable, often shifting rapidly, and 
Table 1: Example of limited access order (LAO) coding

$\begin{array}{llc}\text { Category } & \begin{array}{l}\text { Description } \\ \text { Fragile order: }\end{array} & \begin{array}{l}\text { Score } \\ \text { High. }\end{array} \\ \text { Category 1 } & \begin{array}{l}\text { themselves in the face of } \\ \text { external threats; typically break } \\ \text { up due to instability }\end{array} & 1 \\ \text { Fragile order: } & \begin{array}{l}\text { Coalitions can sustain } \\ \text { themselves in the face of } \\ \text { extedium. } \\ \text { Category 1 }\end{array} & 2 \\ & \begin{array}{l}\text { organization of trade; coalitions } \\ \text { fragile }\end{array} & \\ \text { Basic order. } & \begin{array}{l}\text { Durable and stable } \\ \text { organizational structure }\end{array} & 3\end{array}$

dependant on the individual identity and personality of the coalition members." In contrast, basic states "sustain a durable and stable organizational structure for the state ... public institutions ... [and] provide standard solutions to reoccurring problems: succession of a leader, succession of elites, determination of tax and tribute rates, and division of spoils of conquest." 8

We transcribed North, et al.'s descriptions of fragile, basic, and mature natural states into a taxonomy that can be coded (see Appendix, Table A.1). As it turns out, for many regions of Nigeria this threefold division can in fact be made more detailed, and thus we elaborated the taxonomy to include Fragile Order High, for the least well-ordered regions, and Fragile Order Medium, for those with slightly greater levels of institutional capacity. For each type of LAO "state" we developed eight categories which describe the effectiveness of elites at projecting order. Each numbered category is broadly comparable to the same number in the other types of LAO "states." For example, our first category focuses on the durability of elite coalitions which become progressively more stable as we move from low-order to higher-order LAO states (see Table 1 for an example and Appendix Table A.1 for the full table).

Next, we take the borders of the colonial state as the units of analysis. These were used to calculate regional levels of public goods provision in the 20th century. Until recently, these provincial borders, established by the British, were relatively stable and were used by post-colonial governments for purposes of census-taking, administration, and public goods allocation. For each province we identified ethnic groups via the Harvard Africa Map, and the geographic limits of the pre-colonial LAO "states" through analysis of primary and
Table 2: Pre-colonial order scores by source

$\begin{array}{lcccc}\text { Province } & \text { (1) } & \text { (2) } & \text { (3) } & \text { (4) } \\ \text { Kano (Katsina) } & 40 & \text { Hausa } & \text { No data } & 2 \\ \text { Abeokuta } & 25 & \text { Yomba } & 1950 & 3 \\ \text { Ondo } & 20 & \text { Ekit-Yoruba } & 1950 & 3 \\ \text { Oyo } & 25 & \text { Yoruba } & 1950 & 3 \\ \text { Calabar } & 15 & \text { Ido-Edo } & 1950 & 1 \\ \text { Owerri } & 15 & \text { Ido-Edo } & 1950 & 3\end{array}$

Notes: (1) North, et al. taxonomy score; (2) ethnic group (Murdock); (3) date of Murdock observation; (4) levels of Jurisdictional Hierarchy in Murdock, code 32r.

secondary sources. Using sources we determined just which taxonomic class best fit the ethnic groups or states within the province in the time period just before the advent of colonial rule in the 1870s and 1880s. For example, for the province of Kano (or Katsina) we identified four secondary sources which covered the relevant period. We went through each part of the taxonomy to see which item/s best matched the descriptions in each of the sources in regard to various degrees of state capacity. For instance, for Kano we decided that it best fit Basic Order Category 1 because throughout the century a series of administrative reforms reduced the powers of regional elites and centralized government. This served to promote stability and minimized conflict which meant that the region suffered few serious political or military disruptions. In this instance, the province was awarded a score of 3 points for Basic Order Category 1. In the case of Abeokuta province, also based on four sources, we awarded 2 points as we felt that the sources indicated that the province fit better with the descriptor in the Fragile Order: Medium category. This because elites were able to form coalitions to both defend themselves and to organize offensive warfare while also recognizing the nominal authority of a king. However, unlike in Kano, coalitions were never durable and different towns or areas fiercely and successfully guarded their independence. ${ }^{9}$

This process of identifying differing degrees of pre-colonial order exercised by elites across the entire country was always based on our subjective judgement. In addition, for some provinces primary and secondary data was unavailable. In these instances we made an estimate based on our conclusions from other areas. However, the advantage is that our analysis is based on a widely-cited study of institutional capacity and, more importantly, focuses on state development as it existed before colonialism. The results suggest a rather different pattern than that gleaned from Murdock (see Table 2). For example, according to the ethnographic Atlas the province of 
Kano (Katsina) had fewer levels of "Jurisdictional Hierarchy" (code 32r) and was therefore less centralized than that of Abeokuta.

However, in the case of Kano (Katsina) province, Murdock's Atlas is looking only at the Hausa ethnic group. Although Hausa constituted the majority of the population, in the 19th century, the province was a significant part of the Sokoto caliphate, ruled by a coalition of a dominant Fulani elite along with prominent Hausa families and with a common conception of government based on both Islamic law and West African state precedents. The state was able to impose regular, standardized taxation, its institutions were robust enough to ensure relatively smooth transitions from one ruler to the next and, as mentioned, it was developing an increasingly centralized administration. In addition, as a political entity it was able to engage in complex activities such as to maintain a permanent army and to regulate long-distance trade.

In contrast, the Yoruba city states in Abeokuta did not have the same institutional capacity to project order. They were able to field armies in defense of their territory, maintained a degree of regional unity through promotion of the Ogboni secret society, and project common forms of hierarchal organization. But while the elites were able to create a degree of stability and sense of common identity, any attempts at greater degrees of centralization with one town or group gaining ascendency were largely failures. Even the most significant town, Abeokuta, was not considered at the time to have been run as a coherent town but as a conglomeration of villages over which the ruler had nominal authority. ${ }^{10}$

\section{Public goods provision data}

We collected annual data on public goods provision at the provincial level, which in most of British West Africa was the highest administrative unit within a colony (see Figure 1; Table 3). ${ }^{11}$ The colonial administration invested in three public goods: education, health, and infrastructure. Every year British officials recorded how many teachers, schools, doctors, and hospitals were needed and how much of the collected local revenues and budget was allocated for public works. This detailed register enables us to retrieve original annual data for the colonial period from four types of annual government reports, namely the Administration Reports, Sessional papers, Correspondence letters, and the Bluebooks of Statistics. These four types of reports start at the beginning of the 20th century and continue until the late 1950s.

Regarding education, we collected data on the number of teachers, the number of schools, and enrollment rates per province for each year between 1905 and 1959. We normalized these figures per 10,000 inhabitants and aggregated them into
Table 3: Descriptive statistics

$\begin{array}{lcccc}\text { Variable } & \text { Obs. } & \text { Std. dev. } & \text { Min. } & \text { Max. } \\ & & & & \\ \begin{array}{l}\text { Pre-colonial } \\ \text { order index }\end{array} & 19 & 12.763 & 8.000 & 46.000 \\ & & & & \\ \text { Education } & & & & \\ 1910 \mathrm{~s} & 19 & 5.131 & 0.940 & 17.120 \\ 1920 \mathrm{~s} & 19 & 3.207 & 1.430 & 11.290 \\ 1950 \mathrm{~s} & 19 & 3.748 & 0.240 & 13.080 \\ 1960 \mathrm{~s} & 19 & 3.376 & 0.850 & 12.920 \\ 1980 \mathrm{~s} & 19 & 2.825 & 2.120 & 11.580 \\ 1990 \mathrm{~s} & 19 & 1.243 & 3.560 & 7.570 \\ 2000 \mathrm{~s} & 19 & 2.106 & 1.510 & 9.970 \\ & & & & \\ \text { Health } & & & & \\ 1910 \mathrm{~s} & 19 & 4.322 & 0.330 & 13.170 \\ 1920 \mathrm{~s} & 19 & 4.106 & 0.290 & 12.330 \\ 1950 \mathrm{~s} & 19 & 3.543 & 0.700 & 10.390 \\ 1960 \mathrm{~s} & 19 & 2.769 & 1.380 & 11.000 \\ 1980 \mathrm{~s} & 19 & 1.318 & 3.330 & 7.940 \\ 1990 \mathrm{~s} & 19 & 0.772 & 4.270 & 7.510 \\ 2000 \mathrm{~s} & 19 & 1.691 & 2.440 & 7.500 \\ & & & & \\ \text { Infrastructure } & & & & \\ 1910 \mathrm{~s} & 19 & 3.877 & 0.460 & 12.320 \\ 1920 \mathrm{~s} & 19 & 1.599 & 1.710 & 8.880 \\ 1950 \mathrm{~s} & 19 & 2.428 & 1.970 & 11.680 \\ 1960 \mathrm{~s} & 19 & 3.244 & 1.270 & 12.670 \\ 1980 \mathrm{~s} & 19 & 5.218 & 0.570 & 18.880 \\ 1990 \mathrm{~s} & 19 & 1.965 & 2.700 & 9.800 \\ 2000 \mathrm{~s} & 19 & 3.500 & 0.940 & 15.900\end{array}$

Note: All numbers are percentage shares of the total Nigerian budget allocated to a specified province. For example, the Max. figure of the Education 1910s variable shows that 17.12 percent of Nigeria's total educational budget was allocated to the province which received the highest share of that budget in the years between 1900-1910.

ten-year averages which we then use as a proxy of investments in education. Similarly, we used the number of doctors, medical staff, and health facilities such as hospitals, dispensaries, and hospital beds as a proxy for health investments per 10,000 inhabitants. Finally, we collected the annual figures of road miles, railway miles, and telegraph line miles as well as the number of wells and bridges per province as a proxy of investment in public works.

For the post-colonial period, we collected data from the annual federal digest of statistics, various five- and ten-year development plans, several censuses, and the Central Bank of Nigeria. We retrieved information for each year available between 1960 and 2010 and used the ten-year average numbers of education, health, and public works per 10,000 of the population as proxies for post-colonial development. To 

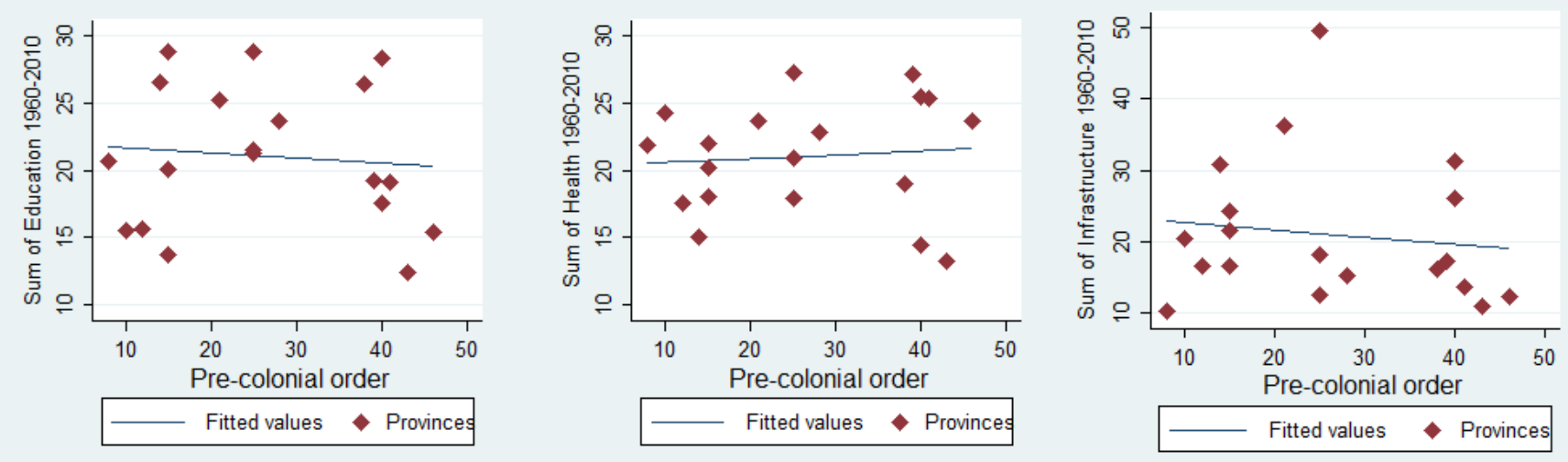

Figure 2: Pre-colonial order and 1960-2008 sum of education, health, and infrastructure.

compare the data across provinces, we created decadal percentage shares: Table 3 shows minimum and maximum shares across the 19 provinces for each decade for each public goods indicator. It is thus possible to see the spread of the share of public goods investments at the subnational level. From a comparative methodology perspective, we believe that this is an effective way of illustrating differences between and among provinces. But another reason why we treated our data in this decade-by-decade manner was that we wanted to highlight changing investment patterns following historical events of outstanding importance - such as multiple regime transitions, the Biafra (civil) war, and the discovery of oil—whose longterm impact would not readily be evident in a year-by-year time series.

In each case, we used outcome variables, not state budget allocations. We did this for two reasons. First, using revenue and expenditure to measure public goods provisions can be misleading as an indicator as throughout the 20th century there often was a mismatch between the distribution of resources and the results on the ground. For a start, in the colonial era much of the investment in human capital was undertaken by nongovernmental actors, such as mission stations, meaning that an analysis of governmental spending alone would not provide an accurate picture of levels of public goods provision. Moreover, in the post-colonial era political bargaining and corruption ensured that large proportions of state budgets were misappropriated or stolen. There are also the difficulties faced in disentangling the reality of government spending from the byzantine complexity of official financial accounts. In contrast, concrete outcomes, such as the number of hospitals, children in school, or kilometers of roads, can be more easily measured and verified and, more importantly, capture the reality of human and physical capital investments. The second reason for choosing our specific variables is that they were used by both colonial and post-colonial governments and therefore allow for consistent comparison over time. ${ }^{12}$

\section{Results and discussion \\ Aggregated}

To investigate whether or not there exist robust past-to-present correlations, we aggregated each outcome variable (education, health, and infrastructure) by adding all each variables' numbers from 1960 to 2008 and created three new variables, sum of post-colonial education, health, and infrastructure. This exercise aimed at falsifying hypotheses of path dependency stemming from centralized pre-colonial orders in Nigeria and carrying over to post-colonial public goods provision. To this end, we ran simple OLS regressions for each of the three public goods, and all of the estimated coefficients indeed turned out to be statistically insignificant. As seen in Figure 2, there does not appear to be a (statistically significant) trend, positive or negative, which implies that increasing pre-colonial order levels do not predict present-day outcomes. This finding casts doubt on that portion of the literature which champions the hypothesis of long-term path dependencies.

\section{Pre-colonial order and public goods provision}

To estimate the effect of pre-colonial order on public goods for each province, we ran several simple OLS regressions (equivalent to simple scatterplots between the two variables) using the newly constructed province-level measure of pre-colonial order as the dependent variable against each indicator for each decade in the sample. In this way, we aimed to investigate whether a consistent correlation, positive or negative, exists between pre-colonial order and (a) education, (b) health, and (c) infrastructure throughout the century. Table 
Table 4: Education, health, and infrastructure correlations with pre-colonial order

\begin{tabular}{|c|c|c|c|c|c|c|c|}
\hline Variable & 1910 & 1920 & 1950 & 1960 & 1980 & 1990 & 2000 \\
\hline \multicolumn{8}{|l|}{$\underline{\text { Panel A: Education }}$} \\
\hline Pre-colonial order & $\begin{array}{c}-1.194 \\
(-2.26)^{* *}\end{array}$ & $\begin{array}{c}-1.633 \\
(-1.98)^{* *}\end{array}$ & $\begin{array}{l}-0.938 \\
(-1.38)\end{array}$ & $\begin{array}{l}0.141 \\
(0.15)\end{array}$ & $\begin{array}{c}0.533 \\
(0.49)\end{array}$ & $\begin{array}{c}-4.552 \\
(-2.04)^{* *}\end{array}$ & $\begin{array}{l}-1.084 \\
(-0.75)\end{array}$ \\
\hline R-squared & 0.231 & 0.168 & 0.076 & 0.014 & 0.014 & $0 / 196$ & 0.032 \\
\hline \multicolumn{8}{|l|}{ Panel B: Health } \\
\hline Pre-colonial order & $\begin{array}{c}-1.779 \\
(-3.11)^{* * *}\end{array}$ & $\begin{array}{c}-2.366 \\
(-4.84)^{* * *}\end{array}$ & $\begin{array}{c}-1.925 \\
(-2.66)^{* *}\end{array}$ & $\begin{array}{l}1.573 \\
(1.51)\end{array}$ & $\begin{array}{l}2.313 \\
(1.02)\end{array}$ & $\begin{array}{l}-5.356 \\
(-1.41)\end{array}$ & $\begin{array}{c}-2.883 \\
(-1.77)^{*}\end{array}$ \\
\hline R-squared & 0.363 & 0.579 & 0.293 & 0.116 & 0.057 & 0.105 & 0.156 \\
\hline \multicolumn{8}{|c|}{ Panel C: Infrastructure } \\
\hline Pre-colonial order & $\begin{array}{c}1.705 \\
(2.50)^{* *}\end{array}$ & $\begin{array}{c}2.677 \\
(1.98)^{* *}\end{array}$ & $\begin{array}{l}-0.299 \\
(-0.24)\end{array}$ & $\begin{array}{l}0.643 \\
(0.69)\end{array}$ & $\begin{array}{l}-0.345 \\
(-0.59)\end{array}$ & $\begin{array}{l}-1.017 \\
(-0.65)\end{array}$ & $\begin{array}{l}-0.833 \\
(-0.97)\end{array}$ \\
\hline R-squared & 0.268 & 0.171 & 0.003 & 0.019 & 0.019 & 0.024 & 0.052 \\
\hline
\end{tabular}

Note: Slope coefficients are shown in the first row of each correlation and t-statistics are shown in parentheses. Levels of statistical significance at which the null hypothesis is rejected: *** 1 percent; ** 5 percent; * 10 percent.

4 shows statistically significant negative correlations for the two human capital measures - education and health (Panels A and $\mathrm{B}$ in Table 4) — with pre-colonial political order until the beginning of the 1950 s.

This finding can be explained in that the colonial state was determined to preserve the pax colonia which it established after the violent conquest of Nigeria. Following laissez faire economics and indirect rule pioneered by the colony's first governor, the colonizers were largely successful in imposing a period of peace and stability. This however required the active cooperation of powerful local elites. The vast majority of European education and health investments were made by nongovernmental missionary organizations, and powerful Muslim emirs of northern Nigeria viewed them as a threat to their authority. Due to their preoccupation with maintaining order, the colonial regime was often actively hostile to mission activity in the areas formally part of the Sokoto caliphate. In contrast, missions had been operating since the 19th century in the more decentralized Southwest. In these areas, existing elites never had the power to block the spread of mission schools or health facilities, which often provided opportunities for social advancement by members of less privileged groups. The net effect was, however, negative such that an increase in pre-colonial order is associated with smaller health and education investments in the first part of the 20th century. ${ }^{13}$

In terms of physical capital, the correlation with precolonial order is positive (a higher level of order is statistically associated with higher levels of infrastructure investment) and is relatively robust throughout the colonial era until the independence period. This can be explained in that the principal government investment in Nigeria over this period was the construction of the railway and roads from Lagos to Kano which linked the more ordered territories of the Yoruba and the former Sokoto caliphate. We suggest that indigenous elites supported physical infrastructure investments because this assisted their motive to broadcast power, and the absence of which, as mentioned, could have posed a threat to their authority. It also seems that these patterns, across all three variables, were fairly constant throughout the period of colonial rule as the decade-by-decade correlations remain strong.

\section{The post-colonial break in public goods provision}

For the period after the second world war and leading up to independence in 1960, our findings indicate a break in the patterns established during the previous decades (see Figure 3 ). The key to understanding this break lies in the ever-increasing levels of instability caused by changing British policies toward political reform and public goods provision, which culminated in the Biafra war and an ongoing conflict over oil resources. The second world war had led to a boom in the Nigerian economy as demand for resources and therefore prices rose. The end of the war then brought about a severe economic slump and also the return of combat veterans less willing to accept rule by a clique of white men. Rising agitation led to a number of significant changes and power devolved to three regional blocks - the North, Southwest, and Southeast - in the so-called "tripartite system of government." Within each of these regional blocks "a single ethnic block came to political dominance and other minority groups felt insecure and 

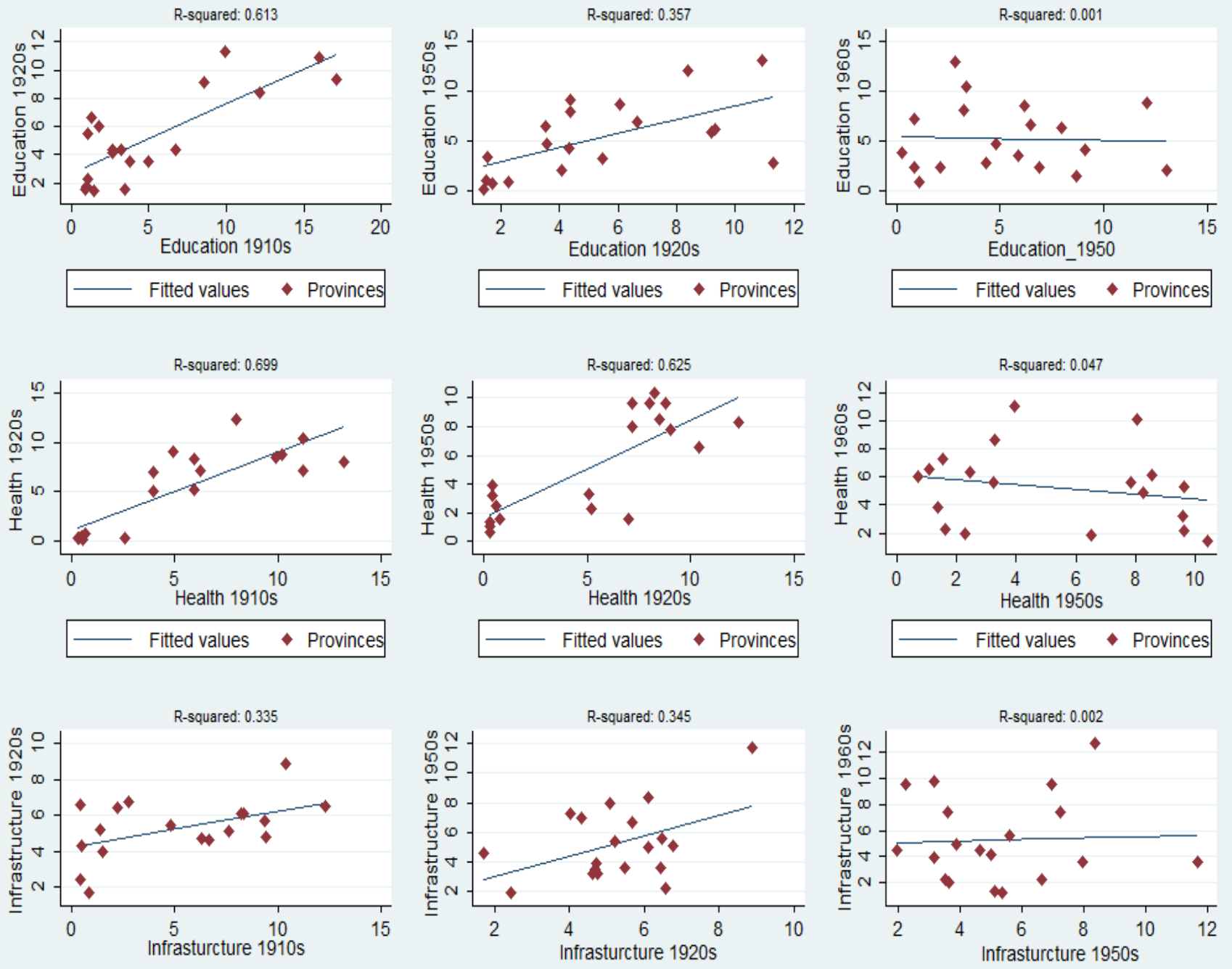

Figure 3: Decade-by-decade correlations, capturing continuity.

disadvantaged." None of the competing groups trusted the others, which led to increasingly bitter struggles to control the center with little incentive to compromise. This escalating tension, fueled by the potential rewards of political victory, seems responsible for the break in the previous pattern of all public goods investments. ${ }^{14}$

\section{The rewards of political power}

As from the 1940s, the British began to centralize government power and increase government spending through 10-year development plans and marketing boards, which controlled prices and output of major export commodities. Not only were such initiatives often ineffective, but it meant that capturing control of the center ensured considerable powers of redistribution, which had little to do with ideology but instead were "widely perceived as an area for the advancement of individual and community interests ... the steady expansion of state patronage in which political considerations rather than economic criteria were paramount [and] adversely affected the allocation of resources." Gradually, Nigerians came to play a dominant role in business, which in the early colonial period had largely been in the hands of foreign firms. Their financial support to regional parties was rewarded with handouts made possible by the new political system. This fusion of the worlds of business and politics made the former inefficient and the latter corrupt and saw the rise of a new breed of politician typified by Chief Nanga of Chinua Achebe's satire A Man of the People (1966). This ensured that the oil boom of the 1960s did not lead to an improvement in living standards for the majority of Nigerians but fueled political conflict among elites 

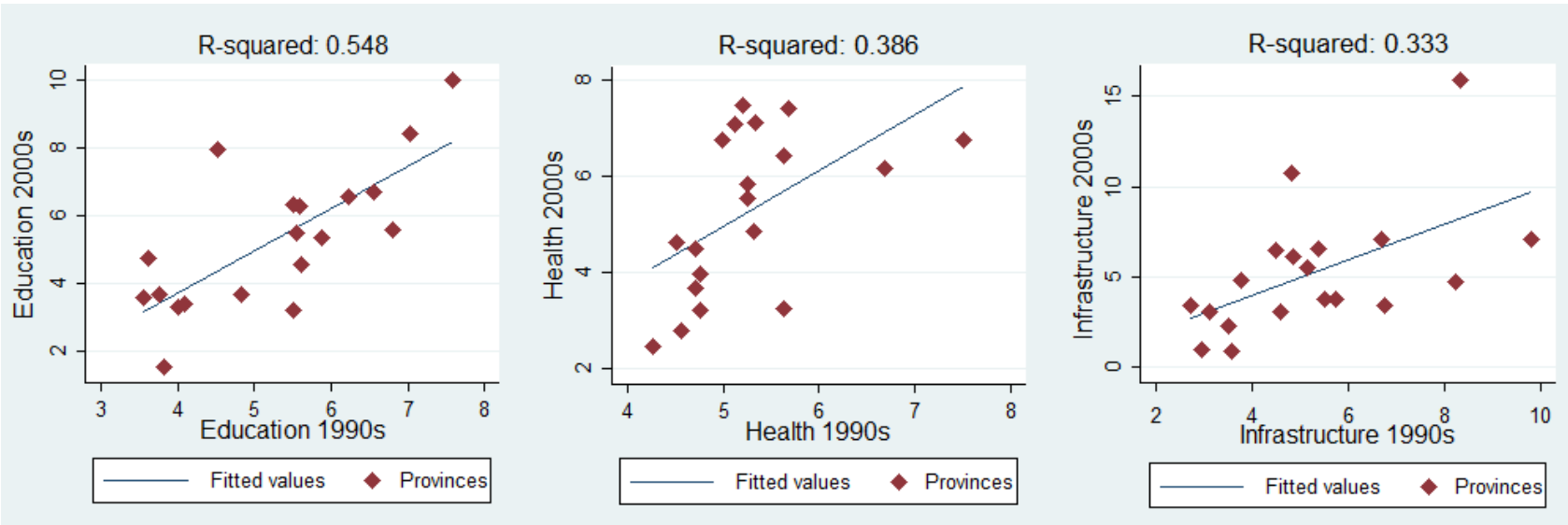

Figure 4: Recapturing continuity and the establishment of democracy.

who wanted access to this source of revenue and funding. ${ }^{15}$

At independence the new politicians who took over from the British thus came to power with the support of their own regions and ethnic groups and with few constraints on their exercise of power and patronage. The military coups of Ironsi and Gowon and the Biafran civil war only served to create a precedence of military rule in which state power was increasingly centralized in the hands of ever-changing elites with few checks on their powers to distribute largess to consolidate their positions and regimes. In terms of investment this was in part fueled by a feeling on the part of northern Nigerians that the South had so far enjoyed far higher levels of development and it was therefore necessary to reallocate funds to "catch up." This resentment was to lead to the massacre of southerners who had emigrated to the North and were seen to be taking jobs and business away from less skilled northern workers. No attempt was made to pursue policies that would encourage ethnic integration or tolerance and that might have led to positive economic outcomes. Instead, politicians could use violence as a justification for unlawful action, which would benefit themselves and their support base. ${ }^{16}$

Coups and civil conflict undermined or swept away the power of old elites and although some, such as the northern emirs, still held considerable power and prestige, they no longer constituted a dominant political class, even within their former territories. Instead, power over the distribution of Nigeria's wealth came to be held by a new breed of military rulers and politicians, characterized by policies of regionalism, military federalism, and nepotism. Unsurprisingly, the factors which had influenced the allocation of government funds in the era of colonialism no longer applied. More importantly, foreign rule no longer imposed political stability, which meant that it was impossible to establish any degree of continuity in investment policy and that at least partially explains why our data do not show any decade-by-decade correlations between the 1950s and 1980s. ${ }^{17}$

\section{Peace and continuity}

Not until the reestablishment of civilian government in the 1990s did any kind of meaningful pattern reemerge, with numbers from the 2000s correlating with those of the previous decade for all measures of public goods provision (see Figure 4). Until then, even the huge wealth accrued from oil revenues had little positive impact on development outcomes as the wealth was routinely misappropriated and, in some regions, was a source of conflict. While hardly ideal, only during the last 20 years has civil administration been at least partly constrained and held accountable by the democratic process. More importantly, this is Nigeria's longest period of relative peace and stability since the imposition of the pax colonia, thus allowing for greater levels of continuity. But since this reemerging pattern does not seem linked in any way to either the events or the political structures of the pre-colonial or colonial eras, we conclude that it is in fact a new pattern, and that it is in the period from independence to the end of military rule that explanations of present-day outcomes are more likely to be found. ${ }^{18}$

\section{Conclusion}

This article examined long-term changes in the patterns of public good provision in Nigeria across the 20th century. Using a newly constructed index of pre-colonial order, along with an extensive regional level data set, we find that socio-political conditions that existed before the arrival of European rule have not had a persistent influence across time and, in this instance, do not provide a satisfactory explanation for modern outcomes. 
We argue that in the case of Nigeria patterns of path dependency were highly susceptible to periods of peace and security. During the pax colonia, the relative peace imposed by the early colonial state seems to have allowed pre-colonial institutions to determine the nature of public goods provision until the second world war. Conversely, our findings suggest that the insecurity and instability of the second half of the 20th century - the result of a complex and damaging process of decolonization, regionalism, and military federalismeffectively broke the link to the country's past. Our evidence suggests that the combined effects of state failure, the rise of regionalism, and (violent) conflict were responsible for the absence of patterns in our measures of human and physical capital until the restoration of more stable civilian government in the 1990s.

Beyond this specific findings, this article contributes more generally to the literature on the degree to which institutional factors bear on development outcomes in Africa. First, we provide a new approach to the measurement of pre-colonial state capacity. In our view, our measure better captures historical reality than does Murdock's Atlas. Second, our decade-by-decade analysis shows the value of examining patterns of long-term historical change so as to the determine exactly how the past may or may not continue to influence the present. In particular, policymakers should be wary of assuming that Africa's history is deterministic, and we expect that additional, data-driven, local case studies will yield illuminating results about the relative role of the pre-colonial, colonial, and post-colonial periods on development today. Third, our findings provide support for greater entrenchment of democracy and long-term political stability if Nigeria's people are to receive equitable shares of the country's investments in public goods.

\section{Notes}

For their valuable comments on previous drafts of this article we are grateful to Anne Booth, Mirjam de Bruijn, James Fenske, Ewout Frankema, Kate Frederick, Michiel de Haas, Elise van Nederveen Meerkerk, Hanaan Marwah, Pieter Woltjer, the participants of the New Frontiers in African Economic History Workshop at the London School of Economics and Political Science (25-26 October 2014), and several anonymous reviewers. Papaioannou gratefully acknowledges financial support from the European Research Council under the European Community's Seventh Framework Programme for the project Is Poverty Destiny? A New Empirical Foundation for Long-Term African Welfare Analysis (ERC Grant Agreement No. 313114) and Dalrymple-Smith from the Dutch Science Foundation for the project Is Poverty Destiny? Exploring Long Term Changes in African Living Standards in Global Perspective (NWO VIDI Grant No.
016.124.307). The usual disclaimer applies.

1. Why Nations Fail (see Acemoglu and Robinson, 2012). Quote: Fortin (2014) The book was also chosen by USAID's chief economist as part of his organization's monthly book club: http://blog.usaid.gov/2012/10/usaid-book-club-whynations-fail/ [accessed 31 October 2014]. Significant barriers to growth: Acemoglu, et al. (2005); Rodrik, et al. (2004); Papaioannou and van Zanden (2015). Long-term development: Acemoglu and Robinson (2012). Greater state capacity: Englebert (2000); Gennaioli and Rainer (2007); Michalopoulos and Papaioannou (2013); Osafo-Kwaako and Robinson (2013). Unsatisfactory: See, e.g., Huillary (2011); Osafo-Kwaako and Robinson (2013). Murdock: Murdock (1969). UC Irvine: http://eclectic.ss.uci.edu/_drwhite/courses/index.html [accessed 9 March 2014].

2. Inequality: The most famous example is Acemoglu, Johnson, and Robinson (2005) which claimed to demonstrate that it was the failure of certain parts of the world to adopt European/North American institutional arrangements that led to current-day world income disparities. In the case of Africa such studies have looked at, among other topics, the impact of geography (Gallup, Sachs, and Mellinger, 1999), ethnolinguistic fragmentation (Easterly and Levine, 1997), and the slave trade (Nunn, 2008). Seminal study: Michalopoulos and Papaioannou (2013). Well-cited article: Gennaioli and Rainer (2007). Other scholars: For instance, Austin (2008); Hopkins (2009). Murdock: Murdock and, later, White, never intended to measure "centralization," and many of their observations were recorded well into the colonial era and not limited to precolonial time periods.

3. Third-most populous nation: Economist (2013); Economist (2014). Abrahamic traditions: Falola and Heaton (2008).

4. Negative connection: Papaioannou and van Zanden (2015); Olson (1993).

5. Field of economic history: Englebert (2000); Fenske (2014); Gennaioli and Rainer (2007); Michalopoulos and Papaioannou (2013). Murdock: Murdock (1969; 1981). Percentage of observations: Moreover, in 18 percent of cases no dates were recorded for the observations and in only one instance was an observation taken from before 1900.

6. Notably different: Herbst (2000); Osafo-Kwaako and Robinson (2013). Tilly: Tilly (1990).

7. Herbst: Herbst (2000). Tsetse fly: Alsan (2013). Decreasing circles of influence: Herbst (2000); McKaskie (2003). Sokoto caliphate: Last (1967).

8. Field of NIE: North, et al. (2009). Two characteristics and quotes: North, et al. (2009, pp. 35, 36, 42, 43).

9. Kano secondary sources: Smith (1997); Hogben and Kirk-Greene (1966); Bayero University (1983); Adamu (1999). Few serious disruptions: Smith (1997, pp. 280, 293, 294). Abeokuta secondary sources: Johnson and Johnson (1921); Peel (2003, p. 37); Llyod (1971, p. 28). 
10. Our analysis is based on Johnson and Johnson (1921); Peel (2003); Llyod (1971); Adamu (1999); and Smith (1997).

11. For the full data set please contact the authors.

12. Nongovernmental actors: Frankema (2010). Misappropriated or stolen: Osaghae (1998); Marwah (2014).

13. Period of peace and stability: Lugard (1922); Reid (2012). Sokoto caliphate: Lugard (1919); Frankema (2012). Since the 19th century: Latham (1973).

14. Clique of white men: Falola and Heaton (2008). Little incentive to compromise: Forrest (1993); Diamond (1988). For example, the larger population of the northern regions ensured that its party was able to allocate the bulk of the 1962-1968 development plan's expenditure to the North. Also see Falola and Heaton (2008, p. 103).

15. Quote: Forrest (1993, p. 40). Access to revenue and funding: Okigbo, et al. (1989); Ovadia (2013); Collier (1981); Forrest (1994)

16. Power and patronage: Diamond, et al. (2013); Meredith (2011). Catch-up: Diamond (1988, p. 293). Northern workers: Diamond (1988, p. 49); Forrest (1993, p.31). Positive economic outcomes: Jha (2007).

17. Policies of regionalism, military federalism, and nepotism: Adebanwi and Obadare (2010); Osaghae (1998).

18. Source of conflict: Watts (1987, pp. 14-18); Nwajiaku-Dahou (2012). Democratic process: Adebanwi and Obadare (2010); Diamond, Adebanwi and Obadare (2013).

\section{References}

Acemoglu, D., I.N. Chaves, P. Osafo-Kwaako, and J.A. Robinson. 2014. "Indirect Rule and State Weakness in Africa: Sierra Leone in Comparative Perspective." Cambridge, MA: National Bureau of Economic Research. Working Paper No. 20092.

Acemoglu, D., S. Johnson, and J.A. Robinson. 2000. "The Colonial Origins of Comparative Development: An Empirical Investigation." Cambridge, MA: National Bureau of Economic Research. Working Paper No. 7771.

Acemoglu, D., S. Johnson, and J.A. Robinson. 2005. "Institutions as a Fundamental Cause of Long-Run Growth," pp. 385-472 in P. Aghion and S.N. Durlauf, eds. Handbook of Economic Growth. Vol. 1. Amsterdam: Elsevier.

Acemoglu, D. and J.A. Robinson. 2012. Why Nations Fail: The Origins of Power, Prosperity, and Poverty. New York: Random House Digital, Inc.

Adamu, M.U. 1999. Confluences and Influences: The Emergence of Kano as a City-State. Kano: Munawwar Books Foundation.

Adebanwi, W. and E. Obadare. 2010. "Introducing Nigeria at Fifty: The Nation in Narration." Journal of Contemporary African Studies. Vol. 28, No. 4, pp. 379-405. http://dx.doi.org/10.1080/02589001.2010.512737

Alsan, M. 2015. "The Effect of the TseTse Fly on African Development." American Economic Review. Vol. 105, No.
1, pp. 382-410 http://dx.doi.org/10.1257/aer.20130604

Austin, G. 2008. "The 'Reversal of Fortune' Thesis and the Compression of History: Perspectives from African and Comparative Economic History." Journal of International Development. Vol. 20, No. 8, pp. 996-1027.

Bayero University, eds. 1983. Studies in the History of Kano. Kano, Nigeria: Heinemann Educational Books.

Cogneau, D. and Y. Dupraz. 2014. "Questionable Inference on the Power of Pre-Colonial Institutions in Africa." PSE W orking Papers No. $2014-25$. https://halshs.archives-ouvertes.fr/halshs-01018548 [accessed 17 March 2015].

Collier, P. 1981. "Oil and Inequality in Rural Nigeria," pp. 191-218 in D. Ghai and S. Radwan, eds. Agrarian Policies and Rural Poverty in Africa. Geneva: International Labor Organization.

Diamond, L., W. Adebanwi, and E. Obadare. 2013. Democracy and Prebendalism in Nigeria: Critical Interpretations. New York: Palgrave Macmillan.

Diamond, L.J. 1988. Class, Ethnicity, and Democracy in Nigeria: The failure of the First Republic. Syracuse, NY: Syracuse University Press.

Easterly, W. and R. Levine. 1997. "Africa's Growth Tragedy: Policies and Ethnic Divisions." The Quarterly Journal of Economics. Vol. 112, No. 4, pp. 1203-1250. http://dx.doi.org/10.1162/003355300555466

[Economist] 2013. "Faces of the Future." The Economist. 20 June 2013. http://www.economist.com/news/international/ 21579817-lot-more-people-faces-future [accessed 31 October 2014].

[Economist] 2014. "Africa's New Number One." The Economist. 12 April 2014 http://www.economist.com/ news/leaders/21600685-nigerias-suddenly-supersized-ec onomy-indeed-wonder-so-are-its-still-huge [accessed 31 October 2014]

Englebert, P. 2000. "Pre-colonial Institutions, Post-colonial States, and Economic Development in Tropical Africa." Political Research Quarterly. Vol. 53, No. 1, pp. 7-36. http://dx.doi.org/10.1177/106591290005300101

Falola, T. and M.M. Heaton. 2008. A History of Nigeria. New York: Cambridge University Press. http://dx.doi.org/10.1017/CBO9780511819711

Faught, B. 1994. "Missionaries, Indirect Rule and the Changing Mandate of Mission in Colonial Northern Nigeria: The Case of Rowland Victor Bingham and the Sudan Interior Mission." Historical Papers. Canadian $\mathrm{S}$ o c i e t y of $\mathrm{Church} \quad \mathrm{H}$ i s tory. http://pi.library.yorku.ca/ojs/index.php/historicalpapers/a rticle/download/39452/35775 [accessed 17 March 2015].

Fenske, J. 2010. "The Causal History of Africa: A Response to Hopkins." Economic History of Developing Regions. Vol. 25, No. 2, pp. 177-212. http://dx.doi.org/10.1080/20780389.2010.527693

Fenske, J. 2014. "Ecology, Trade and States in Pre-Colonial Africa." Journal of the European Economic Association. 
Vol. 12, No. 3, pp. 612-640.

http://dx.doi.org/10.1111/jeea.12042

Forrest, T.G. 1993. Politics and Economic Development in Nigeria. Boulder, CO: Westview Press.

Forrest, T.G. 1994. The Advance of African Capital: The Growth of Nigerian Private Enterprise. Charlottesville, VA: University of Virginia Press.

Fortin, J. 2014. "At a Quiet Base. Plotting an Assault on South Sudan's Oil Field." The New York Times. 3 April 2014. http://www.nytimes.com/2014/04/04/world/africa/from-a -quiet-rebel-base-plotting-an-assault-on-south-sudans-oil -fields.html?_r=0 [accessed 31 October 2014].

Frankema, E. $20 \overline{1} 0$. "How Missions Made the Difference: On the Origins of Formal Schooling in sub-Saharan Africa." CGEH Working Paper Series No. 5. http://vkc.library.uu.nl/vkc/seh/research/Lists/Seminar\% 20Program/Attachments/49/HowMissionsMadetheDiffer ence.ESGseminar.11.2010.pdf [accessed 17 March 2015].

Frankema, E. 2012. "The Origins of Formal Education in Sub-Saharan Africa: Was British Rule more Benign?" European Review of Economic History. Vol. 16, No. 2, pp. 335-355.

http://dx.doi.org/10.1093/ereh/hes009

Gallup, J.L., J.D. Sachs, and A.D. Mellinger. 1999. "Geography and Economic Development." International Regional Science Review. Vol. 22, No. 2, pp. 179-232. http://dx.doi.org/10.1177/016001799761012334

Gennaioli, N. and I. Rainer. 2007. "The Modern Impact of Precolonial Centralization in Africa." Journal of Economic Growth. Vol. 12, No. 3, pp. 185-234. http://dx.doi.org/10.1007/s10887-007-9017-z

Herbst, J. 2000. States and Power in Africa: Comparative Lessons in Authority and Control. Princeton, NJ: Princeton University Press.

Hillbom, E. 2012. "Botswana: A Development-oriented Gate-keeping State.” African Affairs. Vol. 111, No. 442, pp. 67-89.

http://dx.doi.org/10.1093/afraf/adr070

Hjort, J. 2010. "Pre-colonial culture, Post-colonial Economic Success? The Tswana and the African Economic Miracle." The Economic History Review. Vol. 63, No. 3, pp. 688-709. http://dx.doi.org/10.1111/j.1468-0289.2009.00495.x

Hogben, S. and A. Kirk-Greene. 1966. The Emirates of Northern Nigeria. Oxford, UK: Oxford University Press.

Hopkins, A.G. 1973. An Economic History of West Africa. London: Longman Group Ltd.

Hopkins, A. 2009. "The New Economic History of Africa." The Journal of African History. Vol. 50, No. 2, pp. 155-177.

http://dx.doi.org/10.1017/S0021853709990041

Huillery, E. 2011. "The Impact of European Settlement Within French West Africa: Did Pre-colonial Prosperous Areas Fall Behind?" Journal of African Economies. Vol. 20, No. 2, pp. 263-311.

http://dx.doi.org/10.1093/jae/ejq030

Johnson, S. and O. Johnson. 1921. The History of the Yorubas.
From the Earliest Times to the Beginning of the British Protectorate. London: Routledge.

Jha, S. 2007. "Maintaining Peace Across Ethnic Lines: New Lessons from the Past." Economics of Peace and Security Journal. Vol. 2, No. 2, pp. 81-93. http://dx.doi.org/10.15355/epsj.2.2.89

Latham, A. 1973. Old Calabar, 1600-1891: The Impact of the International Economy Upon a Traditional Society. Oxford, UK: Clarendon Press.

Lloyd, P. 1971. The Political Development of Yoruba Kingdoms in the Eighteenth and Nneteenth Centuries. London: Royal Anthropological Institute.

Lugard, F. 1919. "Revision of Instructions to Political Officers on Subjects Chiefly Political and Administrative, 1913-1918." Nigeria (Colony): Waterlow \& Sons.

Lugard, F. 1922. "The Dual Mandate in British Tropical Africa." London: Blackwood.

Marwah, H. 2014. "What Explains Slow Sub-Saharan African Growth? Revisiting Oil Boom-Era Investment and Productivity in Nigeria's National Accounts, 1976-85." The Economic History Review. Vol. 67, No. 4, pp. 993-1011. http://dx.doi.org/10.1111/1468-0289.12040

McCaskie, T.C. 2003. State and Society in Pre-colonial Asante. New York: Cambridge University Press.

Meredith, M. 2011. The Fate of Africa: A History of the Continent since Independence. London: Public Affairs.

Michalopoulos, S. and E. Papaioannou. 2013. "Pre-Colonial Ethnic Institutions and Contemporary African Development." Econometrica. Vol. 81, No. 1, pp. 113-152. http://dx.doi.org/10.3982/ECTA9613

Murdock, G. 1969. Ethnographic Atlas. Pittsburgh, PA: University of Pittsburgh Press.

Murdock, G. 1981. Atlas of World Cultures. Pittsburgh, PA: University of Pittsburgh Press.

North, D.C., J.J. Wallis, and B.R. Weingast. 2009. Violence and Social Orders: A Conceptual Framework for Interpreting Recorded Human History. New York: Cambridge University Press. http://dx.doi.org/10.1017/CBO9780511575839

Nunn, N. 2007. "Historical Legacies: A Model Linking Africa's Past to its Current Underdevelopment." Journal of Development Economics. Vol. 83, No. 1, pp. 157-175. http://dx.doi.org/10.1016/j.jdeveco.2005.12.003

Nunn, N. 2008. "The Long-term Effects of Africa's Slave Trades." The Quarterly Journal of Economics. Vol. 123, No. 1, pp. 139-176. http://dx.doi.org/10.1162/qjec.2008.123.1.139

Nunn, N. and L. Wantchekon. 2009. "The Slave Trade and the Origins of Mistrust in Africa." Cambridge, MA: National Bureau of Economic Research. Working Paper No. 14783.

Nwajiaku-Dahou, K. 2012. "The Political Economy of Oil and 'Rebellion' in Nigeria's Niger Delta." Review of African Political Economy. Vol. 39, Issue 132, pp. 295-313. http://dx.doi.org/10.1080/03056244.2012.688805

Okigbo, P.N.C., P.N. Ckigbo, and P. Okigbo. (1989). National Development Planning in Nigeria, 1900-1992. London: J.

The Economics of Peace and Security Journal — ISSN 1749-852X — http://www.epsjournal.org.uk

(C) EPS Publishing, 2015. All rights reserved. For permissions, email: ManagingEditor@epsjournal.org.uk 
Curry.

Osafo-Kwaako, P. and J.A. Robinson. 2013. "Political Centralization in Pre-colonial Africa." Journal of Comparative Economics. Vol. 41, No. 1, pp. 6-21. http://dx.doi.org/10.1016/j.jce.2013.01.003

Osaghae, E.E. 1998. Crippled Giant: Nigeria since Independence. Indianapolis, IN: Indiana University Press.

Ovadia, J. 2013. "Indigenization versss Domiciliation: A Historical Approach to National Content in Nigeria's Oil and Gas Industry," pp. 42-73 in T. Falola and T. Achberger, eds. The Political Economy of Development and Underdevelopment in Africa. Vol 10. London: Routledge.

Papaioannou, K.J. 2014. "Climate Shocks and Conflict: Evidence from Colonial Nigeria." African Economic History Working Paper Series, No 17/2014. Lund: Sweden.

Papaioannou, K.J. and J.L. van Zanden. 2015. "The Dictator Effect: How Long Yars in Office Affect Economic Development." Journal of Institutional Economics. Vol. 11, No. 1, pp. 111-139. http://dx.doi.org/10.1017/S1744137414000356

Peel, J.D.Y. 2003. Religious Encounter and the Making of the Yoruba. Indianapolis, IN: Indiana University Press.

Phillips, A. 1989. The Enigma of Colonialism: British Policy in West Africa. Indianapolis, IN: Indiana University Press.

Reid, R.J. 2012. Warfare in African History. New York: Cambridge University Press. http://dx.doi.org/10.1017/CBO9781139043090

Rodrik, D., A. Subramanian, and F. Trebbi. 2004. "Institutions Rule: The Primacy of Institutions over Geography and Integration in Economic Development." Journal of Economic Growth. Vol. 9, No. 2, pp. 131-165. http://dx.doi.org/10.1023/B:JOEG.0000031425.72248.85

Smith, M. 1997. Government in Kano, 1350-1950. Boulder, CO: Westview Press.

Tilly, C. 1992. Coercion, Capital, and European States, AD 990-1992. Oxford, UK: Blackwell.

Watts, M. Ed. 1987. State, Oil, and Agriculture in Nigeria. Berkeley, CA: Institute for International Studies Press.

\section{Appendix}

Table A.1: A taxonomy of pre-colonial order (category, description, and score)

Fragile Order High 1: Coalitions can only sustain themselves in the face of external threats, typically break up due to instability 1

Fragile Order High 2: Commitments within the dominant coalition are fluid and unstable, often shifting rapidly and dependent on the individual identity and personality of the coalition members 1

Fragile Order High 3: Shocks can easily lead to violence and the creation of a new coalition. Alternatively, shocks can lead to rearrangements with the coalition 1

Fragile Order High 4: Characterized by simple institutional structures / private elite organizations (e.g., secret societies) rarely beyond village level 1

Fragile Order High 5: Elites only commit to observe laws in very limited circumstances (e.g., external threats) 1

Fragile Order High 6: Patron-client networks dominate the organizations within fragile natural states but gains for both sides are very limited 1

Fragile Order High 7: Elites capable of organizing violence for limited periods of time (e.g., external threats) 1

Fragile Order High 8: Simple laws that govern the relationships among individuals based on social identity and stipulate a set of rules that patrons can use to make decision 1

Fragile Order Medium 1: Coalitions can sustain themselves in the face of external threats and for the organization of trade, coalitions fragile 2

Fragile Order Medium 2: Commitments within the dominant coalition show degrees of stability and are not always dependent on the individual identity and personality of the coalition members 2

Fragile Order Medium 3: Shocks can sometimes lead to violence and the creation of a new coalition. Alternatively, shocks sometimes lead to rearrangements within the coalition 2

Fragile Order Medium 4: Characterized by simple institutional structures / private elite organizations that can extend to province level 2

Fragile Order Medium 5: Elites only commit to observe laws to facilitate trade and in the face of external threats but instability prevents societies from forming durable forms of law 2

Fragile Order Medium 6: Patron-client networks dominate the organizations within fragile natural states, potential to accumulate power on both sides 2

Fragile Order Medium 7: Elites capable of organizing violence against internal threats and to maintain trade (monopolies) 2

Fragile Order Medium 8: Simple laws that govern the relationships among individuals based on social identity and stipulate a set of rules that patrons can use to make decisions 2

Basic Order 1: Durable and stable organizational structure 3

Basic Order 2: Standard solution to succession of ruler 3

Basic Order 3: Standard solution to succession of elites 3

Basic Order 4: Standardized tax / tribute rates 3

Basic Order 5: Standardized division of spoils of conquest 3

Basic Order 6: Common beliefs about the behavior among 
elites 3

Basic Order 7: Only organizations with direct connections to the states are durable 3

Basic Order 8: Elite privileges closely aligned with the state 3

Basic Order 9: State used as the vehicle for complicated organizational activities - warfare, foreign trade, religion 3 